\title{
Ecological and biological features and prospects of using Cotinus coggygria in breeding
}

\author{
Olga Emelyanova*, and Andrey Firsov \\ Russian Research Institute of Fruit Crop Breeding (VNIISPK), 302530, Orel, Russian Federation
}

\begin{abstract}
Due to the deterioration of the environmental situation, the requirements for the assortment of woody plants for landscaping territories for various purposes are constantly growing. To form a stable assortment of woody plants with the specified characteristics, it is necessary to use introduced species in the breeding process. The genetic collection of the VNIISPK Arboretum includes more than 310 species, forms and varieties of woody plants, including the Anacardiaceae family R.Br. All representatives of this family are introduced species, one of which is Cotinus coggygria. The purpose of the research is a comprehensive assessment of the ecological and biological features of Cotinus coggygria and its varieties to justify the use in breeding to obtain varieties with economically valuable traits in the conditions of the Central part of Russia. According to the research results, the most promising for use in breeding in order to obtain new varieties is $\mathrm{C}$. coggygria cv. 'Follis Purpureis', which has a number of economically valuable features: winter hardiness, resistance to diseases and pests, complex of decorative qualities. C. coggygria cv. 'Royal Purple' can only be used as a source of resistance to diseases and pests and decorative coloring of leaves.
\end{abstract}

\section{Introduction}

In the context of constantly developing industry and urbanization, cities have become centers that provoke environmental changes on various scales. The material needs of production and humans change land use and vegetation cover, biological diversity and hydraulic systems at the local and regional levels, and waste disposal affects local and global biogeochemical cycles and climate. The state of ecology requires solving the problems of sustainable development of an increasingly urbanized world [1].

The development of landscape design in cities and villages as a means of optimizing the human environment is directly related to the problem of expanding a sustainable and longlasting assortment of ornamental plants. Nevertheless, in urbanized landscapes, trees and shrubs are often exposed to a high level of stress (shading, drought, air and soil pollution), which shortens their life expectancy and reduces their decorative value. Street plantings are particularly strongly affected. Woody plants of parks and squares suffer to a lesser extent. As a result, plants that are familiar to us often lose the ability to perform their functions [2-4].

As a result, specific plant communities with a peculiar species composition are formed in the urban ecosystem. Most of the local representatives disappear already when cities and

\footnotetext{
* Corresponding author: dendrariy@vniispk.ru
} 
towns are laid out. It is difficult for them to acclimatize in an unusual environment, since the new habitat conditions are not similar to natural ones. Some species disappear during the growth of settlements. On the other hand, in the process of landscaping, new species are often used for this region, which can be resistant to urban conditions [5]. The requirements for the assortment of woody plants for territory landscaping for various purposes are constantly growing: durability, decorative effect, resistance to biotic and abiotic environmental factors, suitability for environmental-improving phytotechnologies. To form a stable assortment of woody plants with specified characteristics, much attention is currently being paid to breeding with the involvement of introduced species, forms and varieties as a source material. Botanical gardens and arboretums are engaged in the study of tree introduced species to changing environmental conditions [6].

Arboretum of the All-Russian Research Institute of Ffruit Crop Vreeding (VNIISPK, Russia) is located in the European part of Russia in $368 \mathrm{~km}$ South-West of Moscow $\left(53^{\circ} 00^{\prime} \mathrm{N}\right.$, $36^{\circ} 00^{\prime} \mathrm{E}$ ), in one and a half kilometers from the city of Orel in the vicinity of a busy motorway, the Orel-Bolkhov, being separated by single-row planting of Tilia cordata. To date, the collection of the VNIISPK arboretum has more than 310 species, forms and varieties of woody plants, including 17 orders. The most numerous order in terms of the number of families in the genetic collection of the arboretum is Sapindales Dumort., which includes 5 families $[6,7]$. One of them is Anacardiaceae R.Br. All representatives of this family in our collection are introduced species, one of which is Cotinus coggygria Scop. The purpose of this research is a comprehensive assessment of the ecological and biological features of Cotinus coggygria and its varieties to justify the use in breeding to obtain varieties with economically valuable traits in the conditions of the Central part of Russia.

Cotinus coggygria is a woody plant. The life form is a large shrub or a small tree with a spherical or umbrella-shaped crown and a well-developed root system, living up to 100 years. It can reach a height of 10-12 m, but more often - 3-5 m. The area of natural growth is the south of Russia, Ukraine and Western Europe, Moldova, South-Central Asia, China. In these areas, C. coggygria is used as an erosion control, soil protection and utility protection $[8,9]$. It is also of great importance for medicine [10]. Having a number of decorative features and high drought resistance, C. coggygria is used in landscape construction, including the landscaping of roofs [8, 11-13].

\section{Materials and methods}

The objects of the study were plants of Cotinus coggygria and its varieties growing in the genetic collection of the VNIISPK arboretum (table 1). The studies were conducted from 2016 to 2020 using the following methods: determination of winter hardiness - visually in the field after the completion of budding on a 7-point scale of P.I. Lapin and S.V. Sidneva [14], where 1 is the highest score of winter-hardiness; the general condition of plants on a 3point scale of A. G. Golovach [15], where 1 is the best condition; determination of resistance to diseases and pests - by visual inspections, considering the influence of this factor on the decorative effect on a 3-point scale (0 - no lesion (damage), 1 - lesion (damage) is present without loss of decorative effect, 2 - lesion (damage) is present with loss of decorative effect); the degree of flowering and fruiting of plants - on 6-point scales of A. G. Golovach [15], where 5 is the highest score; the degree of decorativeness according to the method of $\mathrm{O}$.Yu. Emelyanova [16]. Calculations and statistical processing of the research results were performed using the Microsoft Excel 2016 software package. 
Table 1. Objects of research and their ecological and biological assessment, points (average for 2016-2020).

\begin{tabular}{|c|c|c|c|c|c|}
\hline \multicolumn{1}{|c|}{ Species } & $\begin{array}{c}\text { Winter } \\
\text { hardiness }\end{array}$ & $\begin{array}{c}\text { General } \\
\text { condition }\end{array}$ & $\begin{array}{c}\text { Degree of } \\
\text { flowering }\end{array}$ & $\begin{array}{c}\text { Degree of } \\
\text { fruiting } \\
\text { annual } \\
\text { degree of } \\
\text { decorative } \\
\text { effect }\end{array}$ \\
\hline Cotinus coggygria & 1.0 & 1.0 & 4.8 & 4.6 & 289 \\
\hline $\begin{array}{c}\text { Cotinus coggygria } \\
\text { cv. 'Follis Purpureis' }\end{array}$ & 1.1 & 1.4 & 5.0 & 1.1 & 371 \\
\hline $\begin{array}{c}\text { Cotinus coggygria } \\
\text { cv. 'Royal Purple' }\end{array}$ & 2.5 & 2.5 & 2.1 & 1.9 & 253 \\
\hline V, \% & 54.7 & 47.6 & 40.8 & 72.4 & 19.9 \\
\hline
\end{tabular}

\section{Results and Discussion}

The weather regime of Central Russia, which largely depends on the movement of air masses coming mainly from the Atlantic and the Arctic, or, less often, from Western Siberia and Kazakhstan, is characterized by variability of atmospheric circulation in some years, which leads to significant deviations of temperature and precipitation values from the average annual data [17]. In summer, cold rains can be replaced by prolonged droughts, which does not significantly affect the growth and development of $C$. coggygria due to its high drought resistance. In the cold season, heavy snowfalls can be replaced by prolonged thaws, and then a sharp drop in air temperature to negative values against the background of the absence of snow cover, which in some years affects the degree of winter hardiness of plants.

Frost resistance, as well as winter hardiness in general, is an important feature in the process of introduction and breeding. This factor depends on the biological characteristics of woody plants, their age and growing conditions $[6,18]$. Nevertheless, according to some researchers, this feature does not always depend on the geographical location of the natural growth area [19]. Frost resistance of plants is usually formed gradually and is achieved in the process of hardening, which takes place during autumn and early winter. Plants slow down and stop growing, enter a dormant period, while simultaneously undergoing hardening phases. Laboratory tests of Z. E. Ozherelieva showed that the species C. coggygria passes well through the hardening stages and is characterized by high frost resistance according to the results of artificial freezing [20]. Our field studies have also shown the high winter hardiness of this object. At the same time, the winter conditions described above negatively affect the winter hardiness of $C$. coggygria varieties (table). The variation coefficient for this feature is approaching the upper limit of the average values. In some years, specimens of the variety 'Follis Purpureis' have minor damage to annual shoots. Nevertheless, the plants recover quickly and this does not affect the decorative effect of the plant as a whole. $C$. coggygria cv. 'Royal Purple' is less hardy. In specimens of this variety, annual shoots often freeze to $100 \%$ of their length. The presence of snow cover increases the winter hardiness of this object. At the same time, frequent freezing limits the growth and reduces the decorative effect of the object in the study conditions.

One of the important indicators in the selection of parental pairs in the breeding process is their resistance to pests and diseases. During the research period, no disease damage and pest damage were recorded on C. coggygria plants and its varieties.

Flowering and the possibility of setting full-fledged seeds in ornamental plants are both one of the decorative qualities and the main factor for obtaining hybrid seeds. According to the degree of flowering, the average variability of objects was observed (table). C. coggygria 
and C. coggygria cv. 'Follis Purpureis' bloomed well every year. From $75 \%$ to $100 \%$ of the flowers bloomed on the plants, counting from the full flowering characteristic of this species. In C. coggygria cv. 'Royal Purple' recorded a weak flowering. The number of flowers did not exceed $25 \%$ of the full flowering of plants of this species, which is associated with the annual freezing of annual shoots. According to the degree of fruiting, the variation coefficient showed a high variability of the trait. The number of full seeds in the inflorescences of $C$. coggygria corresponds to $75-100 \%$ of the characteristic fruiting for plants of this species. In C. coggygria cv. 'Royal Purple' weak fruiting was observed. The number of fruits, respectively, did not exceed $25 \%$ of the possible one for this species. On plants of $C$. coggygria cv. 'Follis Purpureis' only single fruits were observed. Nevertheless, this did not affect the size and decorativeness of the panicles formed after flowering.

The assessment of the general condition of the objects was carried out by us at the end of the growing season of each year of research. On this basis, the average variability of objects was observed. Studies have shown that $C$. coggygria has good vitality. All specimens are well developed, have well-developed shoots, buds and leaves of typical color, bloomed well and bore fruit. Plants of C. coggygria cv. 'Follis Purpureis' have an average vitality due to the low fruit setability. In C. coggygria cv. 'Royal Purple' the growth of shoots is insignificant, the degree of flowering and fruiting is low, which indicates the weak vitality of this variety under experimental conditions.

Decorativeness is an aesthetic concept, and, therefore, subjective. Nevertheless, it is always possible to identify certain qualitative and quantitative characteristics that can be evaluated. The degree of decorativeness of the objects of the study was determined considering the dynamics of changes in decorative features during the year [16, 21]. In accordance with this method, a monthly assessment of plants was carried out on six grounds: crown architectonics, leaves, flowers and inflorescences, fruits, color and texture of the bark, originality. For this purpose, a five-point scale was used, where 5 is the highest value. When evaluating the decorative qualities of the leaves, we considered not only their shape and color, but also the severity of the leaf mosaic. If the plants have an unusual crown shape, color of leaves or flowers, this is taken into account by the criterion of "originality" $[16,21]$. The monthly degree of decorativeness for each attribute was multiplied by the weighting coefficients according to the method. According to the sums of the products at the end of the year, graphs were built (fig. 1.), which allow to analyze the variability of the degree of decorative appearance of the species (variety) during the year. Summing up the number of points for all months of the year, we get the total annual degree of decorative plants (table). A low degree of variability was observed for this trait (the coefficient of variation was 19.9\%). Nevertheless, there are some differences by month (fig. 1.). The figure shows that the objects of the study reach the highest degree of decorativeness in July due to the brightly colored foliage and the beginning of the formation of decorative panicles during flowering. The second peak of decorative effect falls on September, when the leaves are painted in bright autumn tones. 


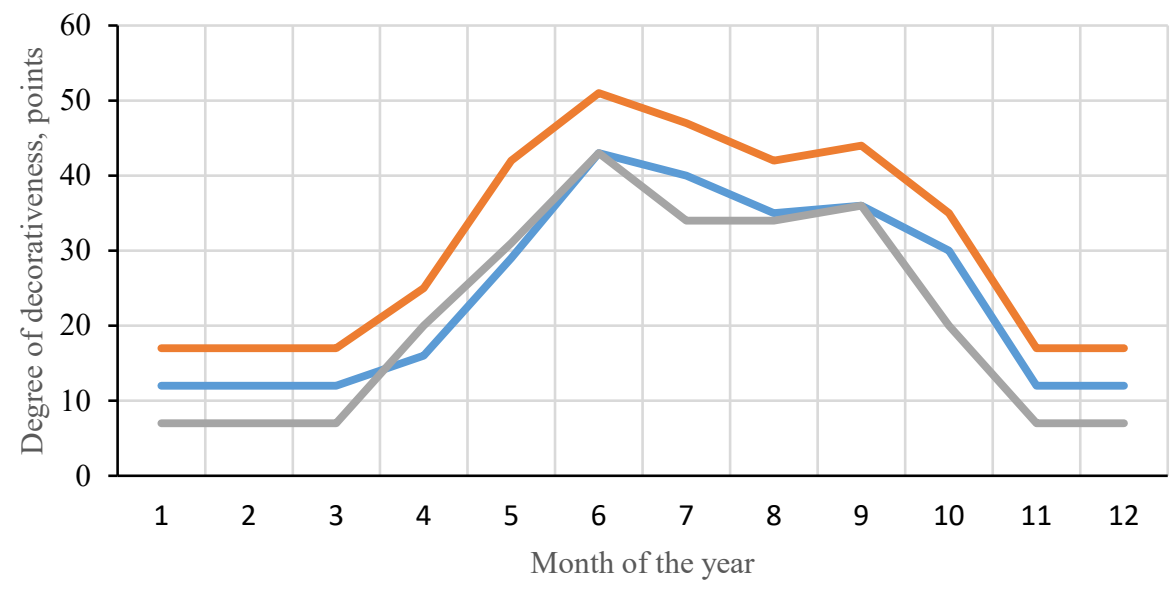

Cotinus coggygria

Cotinus coggygria cv. 'Follis Purpureis'

Cotinus coggygria cv. 'Royal Purple'

Fig. 1. Dynamics of changes in the degree of decorativeness of research objects during the year (average for 2016-2020).

C. coggygria cv. 'Follis Purpureis' throughout the year shows the best results in terms of the degree of decorativeness and has the highest overall annual score (371 points). This variety has a number of decorative qualities that should be paid attention to when selecting parent pairs in the breeding process. This is an oval shape of the crown approaching the correct shape with soft outlines; the color of the leaves: purple in spring, purple-green in summer, bright purple-red in autumn; pink-red fluffy panicles during flowering and fruiting. C. coggygria cv. 'Royal Purple', despite the bright color of the foliage during the entire growing season (bright maroon in spring, purple-black in summer, orange-red in autumn), has the lowest overall annual rating (253 points) when monitoring the complex of decorative features.

\section{Conclusion}

A comprehensive assessment of the ecological and biological features of Cotinus coggygria and its varieties allowed to conclude that $C$. coggygria cv. 'Follis Purpureis' is the most promising for use in breeding in order to obtain new varieties in the conditions of Central Russia, which has a number of economically valuable features: winter hardiness, resistance to diseases and pests, complex of decorative qualities. The only limiting factor is the low fruit setability. C. coggygria is recommended for use in the selection of parent pairs as a source of winter hardiness, resistance to diseases and pests, the general condition and abundance of flowering and fruiting. C. coggygria cv. "Royal Purple" in the conditions of the Central part of Russia can only be used as a source of resistance to diseases and pests and decorative coloring of leaves. 


\section{References}

1. N.B. Grimm, S.H. Faeth, N.E. Golubiewski, C.L. Redman, J. Wu, X. Bai, J.M. Briggs, Global change and the ecology of cities, 319 (5864), 756-760 (2008) doi: 10.1126/science. 1150195

2. A. Sæbo, Z. Borzan, C. Ducatillion, A. Hatzistathis, T. Lagerström, J. Supuka, J. L. García-Valdecantos, F. Rego, J. V. Slycken, Urban Forests and Trees: A Reference Book, 257-280 (2005) doi: 10.1007 / 3-540-27684-X_11

3. O.Yu. Emelyanova, L.I. Masalova, Contemporary horticulture, 4(24), 113-120 (2017) doi: 10.24411/2218-5275-2017-00041

4. N. Yang, L. Cotrozzi, Y. Zhang, Z. Ouyang, F. Zheng, Urban Forestry and Urban Greening, 36, 68-75, (2018) doi: 10.1016/j.ufug.2018.10.007

5. J.G. Pausas, C. Bladé, A. Valdecantos, J.P. Seva, D. Fuentes, J.A. Alloza, A. Vilagrosa, S. Bautista, J. Cortina, R. Vallejo, Plant Ecology, 171, 1-2, 209-220 (2004) doi: 10.1023/B:VEGE.0000029381.63336.20

6. L. Masalova, O. Emelyanova, M. Tsoy, G. Pavlenkova, A. Firsov, E3S Web of Conferences, 6001 (2021) doi: 10.1051/e3sconf/202125406001

7. O.Yu. Emelyanova, A.N. Firsov, L.I. Masalova, Selection and cultivation of horticultural crops, 5 (2), 29-32 (2018)

8. M.K. Akhmatov, School of Science, 6 (6), 4-8 (2018)

9. A.V. Alekseenko, C. Drebenstedt, Ecological Bulletin of the North Caucasus, 14 (4), $13-$ 16 (2018)

10. A.I. Gritsenko, abstract dis. ... candidate of Pharmaceutical Sciences, Volgogr. state Medical University, Pyatigorsk (2016)

11. T. Savi, D. Boldrin, M. Marin, M. Tretiach, A. Nardini, Ecological Engineering, 84, 292300 (2015) doi: 10.1016/j.ecoleng.2015.09.036

12. A. Nardini, S. Salleo, P. Trifilò, M. A. Lo Gullo, EDP Sciences, 60, 297-305 (2003) doi: 10.1051/forest:2003021

13. M. Matusiak, Norwegian Journal of Development of the International Science, 55-2, 11 15 (2021) doi: 10.24412/3453-9875-2021-55-2-11-15

14. Assessment of freezing degree of plant species P.I. Lapin, S.V. Sidneva, Woody plants of the SBS of the USSR Academy of Sciences, Moscow: Nauka, 18-19 (1975)

15. Trees, shrubs and lianas of the Botanical Garden of the BIN of the USSR Academy of Sciences, A.G. Golovach, Leningrad: Nauka, 188 (1980)

16. O.Yu. Emelyanova, Contemporary horticulture, 3 (19), 54-74 (2016) URL: http://journal-vniispk.ru/pdf/2016/3/38.pdf (access date: 05.07.2021)

17. O.Yu. Dubovitskaya, abstract of the dissertation of the candidate of Biological Sciences, VILAR, Moscow (2003)

18. F. Lebourgeois, Cyrille B.K. Rathgeber, E. Ulrich, Journal of Vegetation Science, 21, 364-376 (2009) doi: 10.1111/j.1654-1103.2009.01148.x

19. I.V. Samokhvalova, N.A. Zhamurina, Bulleting of the Orenburg State Agrarian University, 4 (60), 173-176 (2016)

20. Z.E. Ozherelieva, O.Yu. Emelyanova, A.N. Firsov, Contemporary horticulture, 2 (22), 17-24 (2017) doi: 10.24411/2218-5275-2017-00022

21. L. Masalova, O. Emelyanova, M. Tsoy, G. Pavlenkova, A. Firsov, E3S Web of Conferences, 6003 (2021) doi: 10.1051/e3sconf/202125406003 